\title{
The "value" of business archives: assessing the academic importance of corporate archival collections
}

Article

Accepted Version

Hull, A. and Scott, P. (2020) The "value" of business archives: assessing the academic importance of corporate archival collections. Management \& Organizational History, 15 (1). pp. 1-21. ISSN 1744-9367 doi:

https://doi.org/10.1080/17449359.2020.1769676 Available at https://centaur.reading.ac.uk/90727/

It is advisable to refer to the publisher's version if you intend to cite from the work. See Guidance on citing.

To link to this article DOI: http://dx.doi.org/10.1080/17449359.2020.1769676

Publisher: Taylor \& Francis

All outputs in CentAUR are protected by Intellectual Property Rights law, including copyright law. Copyright and IPR is retained by the creators or other copyright holders. Terms and conditions for use of this material are defined in the End User Agreement.

www.reading.ac.uk/centaur 
Central Archive at the University of Reading

Reading's research outputs online 
The "value" of business archives: assessing the academic importance of corporate archival collections

\author{
Andrew Hull and Peter Scott \\ Henley Business School at the University of Reading
}

\title{
Acknowledgements
}

Thanks are due to the archive staff at BT (David Hay and Anne Archer), Boots (Sophie Clapp) and Marks \& Spencer (Katherine Carter) for their help with this study, and to James Walker, Jessica Lutkin, and three anonymous referees, for their feedback and ideas. Any errors are ours. 


\title{
The "value" of business archives: assessing the academic importance of corporate archival collections
}

\begin{abstract}
Corporate archives represent the primary source material for business and management historians. Given that many of the most extensive and important business archives are held and managed by the corporations that generated them, maintaining corporate "buy-in" to preserving records and making archives available to researchers is vital to our discipline. However, corporate archives have to justify their existence and are under increasing pressure to demonstrate the value of their function (and, by implication, their records). Meanwhile, corporate archivists often find it particularly difficult to assess, and demonstrate, the value of their collections for academics and other external stakeholders.
\end{abstract}

This article discusses an initiative to provide academic evaluations of the archival resources of companies that were considering increasing the accessibility of their records for external users. The original idea was a response to a request from Marks and Spencer plc for an academic evaluation of their archives, the success of which led to similar evaluations for BT plc and Boots plc. We outline the criteria by which these firms' archives were assessed, together with how the evaluations informed subsequent decisions regarding the future development of their archives, assisted the firms in gaining external accreditations for their heritage resources, and supported initiatives to boost access, either physically and/or online. We also briefly consider one further consequence of the increased investment in archival resources following these initiatives - the wider interest in, and use of, the archives within the companies concerned - to support a range of business functions and draw on the strengths of their heritage and corporate culture. 


\section{Introduction}

Collaborations between academics and business archivists have become increasingly popular in recent years, mainly involving co-designed research projects to meet business priorities by demonstrating the commercial value of their archival resources in terms of heritage, reputational, brand, and public engagement functions (Green and Lee, 2020). There is also a growing volume of empirical literature, from organization studies and other perspectives, that examines how firms use history as a medium of communication with internal and external stakeholders, for targeted social communication (Donze and Smith, 2018; Smith and Simeone, 2017; Hatch and Schultz, 2017; Foster et. al. 2017; Wishermann, 2014). The tendency to view history as a malleable strategic resource that can support wider corporate goals, together with its implications for both corporate archivists and academics, was the subject of a two-day workshop organised by the Henley Business School's Centre for International Business History in 2019. ${ }^{\mathrm{i}}$

Such projects have been facilitated by the National Archives (TNA), which launched a National Strategy for Business Archives in 2009 (in conjunction with the Society of Archivists and the Business Archives Council), followed, in 2018, by a guide for collaborations between archives and academics, which emphasises the corporate value of accessing academic expertise for initiatives to increase accessibility to external stakeholders and open up new funding streams. ${ }^{\text {ii }}$

For companies, the value of such collaborations has been increased by a growing appreciation that their responsibilities are not only to their shareholders, but to a broad range of internal and external stakeholders who are impacted by their actions. Recent years have witnessed growing corporate awareness of the commercial value of their archives in leveraging heritage, brand history, and corporate culture (Deserno, 2009: 17-18). Corporate 
culture/heritage has been identified as a valuable and unique corporate asset (Barney, 1991), having the potential to make a long-term contribution to society through developing and exploiting a unique company resource. Some corporate archives are being transformed into "business support units" to serve the needs of both the company and these stakeholders, which in turn requires the ready accessibility of their archival resources through online catalogues and/or guides (Gray, 2002).

However, in common with advertising, publicity, and corprorate social responsibility expenditures, the monetary value of such initiatives is very difficult to measure, as their impacts are largely intangilble and may reverberate for a much longer period than that of the initial investment. As the leading business archivist Paul Lasewicz (2014: 203) noted, `Many corporate archives exist as an act of faith - organizations know a corporate archive adds value, but quantifying that value is difficult.' Lasewicz has attempted such an analysis, using survey evidence following IBM's 2011 centennial celebrations (in which the company's history and heritage took center stage), concluding that, 'the use of IBM's heritage was foundational to a very successful effort to improve the company's standing with key constituencies - in terms of both corporate identity mix and tangible fiscal returns. He also reported that this investment in the exploitation of its heritage was instrumental in getting senior IBM executives to see archival resources as "a strategic asset, a significant marketplace differentiator that our competitors cannot match" (Lasewicz, 2014: 115).

An archive is usually of greatest value to firms that are of an age where their history or brand provides some competitive advantage over rivals. However, such benefits aren't automatic, requiring both an accessible archive and a strategy for disseminating the brand history to customers and other key stakeholders. This is equally true for product development and innovation - easy access to the company's technological, design, packaging, and other 
product characteristics (e.g. scent, for perfume) histories, requires a level of accessibility within the organistion that relative few companies currently have (Logan, 2017: 13-15).

From the historian's perspective, access to corporate archives is obviously vital and while the records of many "dead" companies are preserved in public sector repositories, most of Britain's major corporations manage their historical records internally. This has various advantages for the historian, including access to archives of a size beyond the preservation and storage capacities of almost all public sector archives and - in theory - a records management strategy that can ensure efficient transfer of more recent records to the archive when they are considered no longer "current." Similarly, corporate archivists have a strong incentive to work with academic historians, to show the wider relevance and value of the archivist's functions of preserving, curating, and accessing the company's historical resources. (Ataman, 2009: 197).

Companies are (or should be) aware of the value of their archives in terms of key business functions such as marketing, trademark protection and other legal issues, strategic planning, property management, personnel matters, management education, and public relations (Bakken, 1982: 279; Eulenberg, 1984: 31; Anderson, 1982: 264). Yet they are often on much less firm ground when judging the potential academic value of their holdings. For example, Steven L. Wright (1996: 161-2.) found that the historical records U.S. companies typically consider most important often have little historic value in comparison with some other archival materials in their collection that they have overlooked.

Companies have an even more difficult challenge in assessing the overall academic value of their archives - a judgement of importance for cost-conscious firms wishing to evaluate whether the publicity, goodwill, corporate identity, "outreach" and "heritage" value of maintaining an open historical archive outweighs the substantial costs of doing so. 
Corporate archives can only survive if there is management buy-in, to ensure long-term financial and organisational support, which in turn requires evidence of tangible and intangible benefits.

This article discusses an initiative launched by Peter Scott, then director of the Henley Business School's Centre for International Business History (CIBH) and a trustee of the Business Archives Council (hereafter BAC), to provide an academic evaluation of the archival resources of companies that were considering initiatives to increase accessibility for external users. The original idea was a response to a request from Marks and Spencer (hereafter M\&S) to the BAC for advice regarding an academic evaluation of their archival resources, the success of which led to similar requests from BT and Boots. We outline the criteria by which these firms' archives were assessed, together with how the evaluations informed subsequent decisions regarding their archival collections and supported further initiatives to boost access, either physically and/or online. We also briefly consider another consequence of the increased investment in archival resources following these initiatives the wider use of the archives within the companies concerned, to support a range of business functions.

To avoid potential bias, all data for this study were collected via a researcher who had no role in the archival appraisals discussed below. Our methodology mainly involved fieldwork at the three archives, supplemented by documentary sources. The fieldwork mainly involved interviews with relevant archival and other staff of the three companies, though we also sought to obtain corroborating evidence from other sources (principally documents) wherever possible.

\section{The first evaluation: Marks \& Spencer plc}


M\&S established an archive in 1983, originally located in their head office at Baker Street, London, with limited access for academic use (Carter, 2013: 1). Several relocations followed and at the time of the evaluation their archives were held at their Wood Green store in north London. In 2007 M\&S CEO Sir Stuart Rose, who recognised the potential for the Archive to act both as an educational resource and a means of promoting and supporting the M\&S brand, formed a steering group to explore avenues for further developing the collection (Carter, 2013: 2). As part of this initiative, the BAC received a request from the Marks \& Spencer Company Archive for advice regarding the academic value of their records - to feed into the decision-making process regarding possible development of the collection (which was then closed to external users) into an open, catalogued, archive. Peter Scott offered to undertake an academic appraisal, based on his extensive research experience, working on the archives of well over 50 retail and other firms in the UK and USA. M\&S accepted this offer and Scott undertook the analysis in March 2008, based on a week's work in the archive. iii

Scott assessed the academic value of the M\&S Archive (and the archives of the other two companies discussed below) according to three main criteria: the economic and social importance of the company; the extent and comprehensiveness of the archives; and the quality of the materials held (i.e. the potential value of the information that could be extracted from them). Importance is based on many factors, including the economic, social, and cultural significance of the sector(s) in which a firm operates; the company's market share, longevity, and record of innovation (both technical and managerial); the extent to which it has influenced the managerial practices of other companies; the distinctiveness of its corporate culture; and its impacts on stakeholders such as customers, policy-makers, and staff.

Establishing the importance of $M \& S$ was straightforward, as it had long been one of Britain's largest, best-known and most innovative retailers- as evidenced by a number of 
corporate biographies (Rees, 1969; Briggs, 1984; Bookbinder, 1993). Its leading role in the UK high street was already firmly established by the late 1920s, when it introduced an innovative sales formula, including the mass marketing of good quality merchandise at low prices, on the basis of product standardisation (discarding less popular lines and less popular sizes and colours of the remaining lines), cooperative relationships with manufacturers, and trading lower retail margins for higher sales volumes. Other key innovations included an advanced staff welfare policy and particularly sophisticated statistical and accounting systems.

Comprehensiveness reflects the size of the collection, the breadth of the records (are all the functional and territorial activities of the company well-represented), chronological coverage (are certain eras of the company's activities poorly represented, for example early records) and the extent to which the records provide good coverage of activities that the company is well-known for (for example, innovative marketing, personnel, or product development activities).

The comprehensiveness of the archival material was found to be generally good. Particularly from the launch of the public company in 1926, the number of records available for each individual year examined was substantial and their coverage of the different areas of the company's activities was strong. An extensive collection of merchandise artefacts $(4,600$ items), photographs, and other non-documentary materials provides valuable context for the written evidence, as well as being important in their own right. Some gaps were also identified, though this partially reflected the fact that the Archive was not fully-catalogued and the holdings have since been significantly enhanced, through new accessions and full cataloguing. 
Assessing the academic value of an archive is the most time-consuming task, as this involves examining those activities where the company was particularly innovative, or successful, and assessing to what extent the relevant records capture the key processes involved, together with the impacts of these innovations. M\&S scored particularly highly on these criteria. By the 1930s M\&S was extremely advanced in the use of statisticians and specialist managerial staff and was thus able to produce analyses of its activities which were of exceptional sophistication by contemporary standards. This enables researchers to examine the drivers of M\&S's rapidly rising productivity following their adoption of American-style variety chain store management systems in the 1920s (Scott and Walker, 2017a).

Exceptionally valuable quantitative data were matched by rich qualitative evidence.

Overall, the Archive was shown to be a particularly important collection, of considerable value to a wide-range of academic and to other external stakeholders. The report argued that opening the collection to academic researchers would be of great value to scholars of both retail history and wider aspects of British economic, social, and cultural history. It also predicted that $\mathrm{M} \& \mathrm{~S}$ was likely to benefit from making a world-class corporate archive more widely-accessible, in terms of promoting its heritage, achievements, and distinctive corporate culture to both internal and external stakeholders. Further recommendations included the full cataloguing of the collection and exploring ways in which the value of the material could be more effectively utilised and disseminated, both within the company and externally - by developing it as an open access archive.

M\&S viewed the report as making, "a compelling case for the quality and significance of the collection as a research resource"(Carter, 2013: 2). Preparations for the company's $125^{\text {th }}$ anniversary gave the project a sense of urgency and, partly based on Scott's report, a Board decision was made to develop an open access archive. Part of their $125^{\text {th }}$ anniversary celebrations involved a temporary archive exhibition at Leeds University, which was 
originally planned to open for six months; but actually continued for eighteen months owing to its popularity.

The M\&S archival staff saw the main value of Scott's report as providing external verification from an independent leading academic regarding strengths of the collection that the archival staff had, in the main, already recognised. In particular, the summary statement that "Marks and Spencer has a World Class corporate archive which has great potential to be of considerable value to the company, academic researchers and the wider community" was used extensively in the presentation for the M\&S Board, concerning the development of an open corporate archive, in partnership with Leeds University. ${ }^{\text {iv }}$ The archival staff also found it useful in getting a sense of which areas of academic research might make most use of the archive and as independent evidence when applying for designated status for this collection with the Arts Council - which was one of Scott's recommendations. The designation bid was unsuccessful, as the Arts Council did not consider that M\&S had a "unique" story, given there were also other retail firms with long and distinctive histories. However, it was the first retailer to be accredited by the UK Archive Service Accreditation Partnership in March 2018, (placing it among only five percent of all UK archives that have received this recognition).

A purpose-built archival centre, with exhibition space and other facilities, was developed in partnership with University of Leeds - reflecting the firm's origins as a Leeds market trader. Opened in 2012, the Centre had over 15,000 visitors in its first year, together with 150,000 online users for its catalogue and website (Carter, 2013: 2). The M\&S Archive Collection has a remit to: "preserve, document and make available the history of M\&S to support the business needs of the company and its shareholders; to inspire learning and inform research both internally and externally of the company; and to support the needs of the wider community through the opening of its collections to the public" (Carter, 2013: 1). It reports both to the board and to the M\&S Company Archive Interest Company - established 
in 2010 to ensure that the collection is accessible to the public and of benefit to the

community. The archive has a strong education and outreach programme, assisted by having a university-based archive centre and an on-line catalogue (Carter, 2013:1- 2).

\section{[Figure 1 near here]}

By 2017 the collection included over 70,000 items, encompassing all aspects of the company (Carter, 2013: 2). It has attracted a variety of academic users, ranging from student dissertations to major research projects. The new archive has proved an extremely valuable resource for a range of disciplines, including business and management (for core topics such as internationalisation; business ethics; HR; corporate finance; logistics; value chains; and marketing); for textile and clothing technology; fashion; economic, social, and cultural history; and for the history of the built environment, both nationally and locally The staff are currently collaborating on a project with the University of York, examining the changing relationship of elderly people with food and cooking, including making a small financial contribution to the project. Scott's 2008 report is still referenced by the company as evidence of the importance and range of the archival collection. (Carter, 2013: 4-12).

Outreach activities have made the Archive more relevant and accessible to nonacademic audiences, through an events programme and a volunteer programme. More recently, a community outreach programme, commenced in 2014 , has developed various activities, including archive-based reminiscences, where community care groups and people with dementia visit the archive to participate in creative reminiscence projects. ${ }^{\mathrm{v}}$ They have also developed award-winning education activities for schools visits and are working on an online/distance version - in line with the M\&S strategy of being connected to customers and communities. The Archive has also received visits from various other companies, thus disseminating best practice regarding how to develop an archive that serves internal business processes, academics, and a range of other stakeholders. One such visitor was Boots plc., 
which subsequently asked Scott to undertake an evaluation of their archives, as discussed below.

The investment in this archival resource not only provided heritage, corporate identity, and PR benefits, but also substantially increased the use of the records for internal functions, becoming a key business unit for M\&S. ${ }^{\text {vi }}$ This was demonstrated during the $125^{\text {th }}$ anniversary celebrations, where their heritage was promoted in advertisements and limited edition product ranges - the success of which led to further efforts to link current activities to its heritage (Carter, 2013: 2). M\&S also changed their logo to include their date of establishment, as: "We're proud of our heritage, and acknowledged the rich history of our business with the addition of 'EST. 1884' to the M\&S brand mark in 2015." "vii To emphasise their distinctive culture, developed over generations and viewed as, "a fundamental part of how we do business... what makes M\&S different," in 2014 M\&S introduced four new core values, built on the principles that have guided the business since its foundation in 1884 . These values - "Inspiration, Innovation, Integrity and In Touch" - aim to equip all staff to deliver their strategic plans. ${ }^{\text {viii }}$

The Archive has a good internal profile. Despite initial concerns regarding whether anyone from Head Office would visit, "Usage by internal teams is higher than the business ever anticipated it would be." ${ }^{\text {"ix }}$ For general staff induction there is an "archive content package" (a short film package). For senior staff there is an "on-boarding programme". All new directors visit the archive within their first few weeks at M\&S, to gain a better understanding of its brand heritage and core principles. Both the Chairman and CEO continue to email the archivists directly. ${ }^{\mathrm{x}}$ There have also been initiatives to use the merchandise archive to develop heritage brand lines. For example, in April 2016, designer Alexa Chung collaborated with M\&S to develop a new fashion collection, Archive by Alexa, inspired by 
their archival collection, with the aim of, "bringing back to life the golden oldies she felt were missing from the modern high street" (Logan, 2017: 15).

More fundamentally, the archive has been used for strategic decision-making - to tie current strategy to M\&S's core principles. "Almost any project in the business, no matter which part of the business... starts with a 'let's check in with the archive team to see how we have done that in the past." ${ }^{\text {xi }}$ For example, strategy to implement their commitment to reducing packaging was informed by analysis of how the firm coped with less packaging during war-time shortages, while planning for Christmas peak trading is informed by how they responded to the much stronger Christmas sales spikes in previous decades. ${ }^{\text {xii }}$

The partnership with Leeds University has been of value to both parties. For example, they have developed a broad range of opportunities to support young people into the workplace. From mentoring programmes to student projects and work placements, young people were given the chance to work with colleagues across the business. They also collaborated on various initiatives ranging from international business to gender diversity, and supported M\&S charity partners such as Oxfam '(through the Shwop At Work initiative, a scheme where employees donate unwanted clothes). ${ }^{\text {xiii }}$ Other initiatives involved exploring emerging digital learning platforms. Launched in September 2014, "Innovation: The Key to Business Success" was the first Massive Open Online Course (MOOC) for M\&S and attracted the highest number of learners for a University of Leeds course to date.

\section{The BT archives appraisal}

The next archival appraisal was undertaken for the BT Corporate Archive (hereafter BTCA). BT traces its history back to the World's first telecommunications company, the Electric Telegraph Company, formed in 1846. Many other telephony firms were created over the next 60 years, but in 1912 the General Post Office (hereafter GPO) took over nearly all 
private telephony companies and telephone services became a virtual monopoly. Until 1969, the GPO operated as a government department and the Post Master General sat in Cabinet. Following the Post Office Act of 1969, the department became a public corporation with two divisions: Telecommunications and Post. During the 1970s there was political pressure to open up the telecoms market and in 1981 the British Telecommunications Act split the GPO into two corporations. This was followed, in 1984, by the launch of a privatised BT, with initially - just over 50 per cent of the shares sold to the public (the remainder being subsequently sold off in December 1991 and July 1993). ${ }^{\text {xiv }}$

Meanwhile from 1981 the telecommunications market was progressively liberalised, transforming a monopoly utility into a highly-competitive sector. Opening up the market led to a fall in BT's share of fixed voice services (wired telecom networks) from 100 percent in 1984 to 42 percent in 2018, while technological and market changes radically reduced the real cost of telecommunications. ${ }^{\mathrm{xv}}$ The combination of increased competition and falling unit charges has led to several changes in BT strategy over the last 30 years, as they sought new revenue streams, while also delivering cost saving initiatives.

BT has a long history of preserving and sharing its records. In 1876, BT's predecessor - the Post Office Engineering Department - donated artefacts to the Science Museum and, as a public institution until 1984, it had a statutory duty to preserve its records under the Public Records Acts, 1958 and 1967 (Hay, 2004). Despite no longer being a public institution, it continues to preserve its heritage on behalf of the nation as outlined in its Board approved 'Heritage Policy'. xvi

The approach to Scott to undertake an appraisal of their collections, in autumn 2009, was directly inspired by his report for M\&S, which was viewed as having helped their internal case for resources. ${ }^{\text {xii }}$ However, BTCA was more interested in accessing external 
accreditation and raising the public profile of the archive so as to attract more interest from academics and support the development of partnerships with universities and other external bodies - to raise revenue in an environment of falling internal funding. ${ }^{\text {xviii }}$ The Archive was atypical of corporate archives, given that the bulk of its records - those pre-dating privatisation in 1984 - are covered by the Public Records Acts and BT thus has a statutory responsibility to preserve them and make them available to the general public (Hay, 2004).

BT had already engaged in a number of collaborative projects, such as the digitisation of the telephone directories in 2006-2007 to make them more accessible to family historians and other users. BTCA was interested in developing further digitisation projects to make their archival records more accessible online. Thus an appraisal offered the opportunity to better understand how they could position the collection externally, with internal advocacy constituting a subsidiary goal. ${ }^{\text {xix }}$

Following a week's work at BTCA, plus further study of a large number of photographic copies of documents taken during the visit, Scott submitted his report in October 2009. ${ }^{\mathrm{xx}}$ The report used the same criteria as that for $\mathrm{M} \& \mathrm{~S}$ and had a broadly similar structure. Establishing the importance and comprehensiveness of the collection was again straightforward, as BTCA had a comprehensive collection of records from the dawn of telecommunications to the early 1980s (and the records of the largest UK-based telecoms firm thereafter). These included some of the most important communications systems of their times - such as the first international and inter-continental telegraph and telephone cables; the pre-nationalisation telephone companies; the genesis of wireless telegraphy; the telecommunications functions of the Post Office; and the records of BT and its associated companies. 
Establishing the academic value of the records was thus non-problematic. Materials in the collection were identified as being of considerable importance to the study of ICT industries, the more general history of science and technology, and various aspects of business, economic, social, and cultural history. The report also emphasised that the vast wealth of information contained in the archive was (arguably still is) greatly under-utilised largely due to the low level of engagement with this material on the part of the academic community. While fieldwork for the report could only encompass a tiny fraction of the 3,000 linear meters of records in BTCA, it was apparent that there was unusually rich material, suitable for a broad range of academic interests.

The report concluded that, "It is no exaggeration to say that the BT Archive constitutes one of Britain's most important corporate archival collections. There is a huge wealth of valuable material on a broad range of scientific and engineering, management, marketing, and other topics... The collection is of considerable value in terms of the history of BT and its predecessors; the development of telecommunications and broader ICT industries in Britain; and for wider economic, social, and business history topics, constituting a major economic and social record of an industry which impacts on all aspects of British public and private life." ${ }^{\text {xxi }}$ It also noted the potential of the archive's value for BT, in terms of corporate identity, heritage, and branding, for a firm that could reasonably claim to be the world's oldest communications company.

Recommendations included exploring ways in which the material could be more effectively utilised and disseminated, both within the company and externally. One important mechanism for achieving this was via the BTCA web-site. It also recommended applying for UNESCO accreditation and Arts Council designation. Armed with this independent appraisal, BTCA went ahead with applying for these. BT's research archives, $1878-1995$ were included by UNESCO in the UK Memory of the World Register in 2011 as a unique record 
of British scientific endeavour and innovation. They were also awarded Designation status in 2012 by Arts Council England as an important part of the UK's cultural heritage. ${ }^{\text {xxii }}$

The BTCA staff found that the report helped to promote the external academic profile of the archives more widely, which has in turn improved their internal profile. BT now has greater awareness of the importance of history outside the BT history sections of their

archives. For example, the innovation section of their website has a timeline. ${ }^{\text {xiii }}$ Meanwhile various corporate initiatives that initially saw no link with the archives are drawn into it, owing to increasing awareness of the value of its heritage resources. For example, BT has funded a new exhibition at Bletchley Park Museum, on Colossus - the world's first programmable electronic computer - built by a team of GPO researchers for government code breaking during the Second World War ${ }^{\text {xxiv }}$.

\section{[Figure 2 near here]}

BT has sought opportunities to work with external partners, the benefits of which include: providing access to funding normally closed to BT as a company; broadening the audience for the archives; and deepening their own understanding of the collection. Partners include Salford University; Leeds University; UCL; University of the Arts, London; Manchester University; and Royal College of Arts. This has involved work on collaborative masters degrees, Phd programmes and other projects. These were sometimes funded by BT but often with the support of bodies such as the EPSRC, AHRC, and others. Some of these relationships continue, but the biggest partnership project undertaken so far has been the New Connections/BT Digital Archives collaboration with Coventry University.

Following the submission of Scott's report, an invitation letter was sent to Universities UK and the Russell Group to explore partnerships with BT archives. A framework collaboration agreement to secure funding for digitisation initiatives was signed in 
August 2011. They had already identified the Jisc Digitisation and Content Programme as a potential source of collaborative funding. A total of 109 bids were received, 23 of which gained awards. The BT/ Coventry bid was one of 7 from 68 to work on Strand B of the three funding strands. This Mass Digitisation funding stream project was to focus on embedding content in teaching, learning and research. Coventry University, (the lead partner) received $£ 744,873$ to work in partnership with BT on their "New Connections: BT e-archive project." ${ }^{\mathrm{xxv}}$

The objectives of the project were: digitisation of 445,000 documents and images; embedding of an e-archive in the University's own teaching, learning and research work; development of resources for teachers, learners and researchers; and engaging with science and technology enthusiasts through an online platform and interactive gateway. This 20 month project concluded in July 2013. TNA was invited to participate, given their extensive experience with archival digitisation. Priorities included BT's historical photographic image archive (50,000 of their 500,000 prints and negatives); their research reports (an area flagged up by Scott's report); and a range of policy papers and related documents. This led to the launch of the BT Digital Archive in July 2013 - a pioneering project to make a large number of corporate archival papers and images available online, together with an online catalogue of other material held by BTCA (Hay, 2014). BT became the first British company to digitise its historical records for public access on any significant scale, including over half a million photographs, advertisements, letters, and other material, amounting to 50 terabytes of content (Turton, 2017: 304). ${ }^{\mathrm{xxvi}}$

Academic partnerships are very important to BTCA, as they represent a route to funding BT could not apply for directly, given BTCA's status as a company department. Since the report there have been a number of Phd projects based on partnerships with individual universities. These include part of a CPD (Continual Professonal Development) programme 
with the Science Museum and Royal Botanical Gardens, Royal Geographic Society, and the Royal Society. They have just won a third round of funding from the Arts and Humanities Research Council (AHRC) and are planning further applications. Their largest partnership is with Coventry University - involving $£ 1$ million for the digitalisation initiative discussed above. ${ }^{\text {xxvii }}$ In a 2018 interview with Alix Green (Green and Lee, 2020: 37), David Hay, Head of Heritage and Archives at BT, stated that identifying the research value of the archive had opened external funding streams, 'which would be normally closed to us unless we were applying for it in partnership.' The BTCA staff see Scott's report as being a major factor leading to success in these funding bids which, they state, would definitely not have received funding without the their designation and accreditation status, which were achieved using the report. $^{\text {xxviii }}$

\section{The Boots Company Archives appraisal}

John Boot (1815-1860) opened the first Boots store in Nottingham in 1849, though the company rose to prominence through the efforts of his son, Jesse (1850-1931). Jesse Boot worked full-time in his family's herbal medicine shop from the age of 13 . He later moved into proprietary medicines, using a highly successful business formula of buying in bulk, undercutting local competitors, and vigorously advertising low prices to boost stock-turn (Chapman, 2004). He later established own brands to substitute for more expensive nationally advertised ones (subject to retail price maintenance) and employed advertising that directly attacked what he described as the high prices of the established pharmacy trade (Chapman, 2004: 41).

Boots was a pioneer of a form of inclusive, leisure-based, retailing that served a mass, rather than class-based market, before the arrival of U.S.-based retailers - Gordon Selfridge and F.W. Woolworth - who are generally credited with importing this retailing model to 
Britain. By the Edwardian era Boots was also beginning to emphasise services, even hosting art exhibitions at some of their largest stores. This transition owed much to Jesse's wife, Florence Annie Rowe, who was responsible for the development of Boots" "No. 2 department" - selling stationery, books, pictures, silverware and other "fancy goods" - and for introducing lending libraries and cafes into the larger stores (Chapman, 2004; Greenwood, 1977: 15). This assisted Boots in developing large, departmentalised, stores, which were advertised as appealing to both "the classes and masses" (Scott and Walker, 2018: 810). Rapid development of new stores, including the acquisition of various smaller chemist chains, increased Boots' branch network to 180 shops by 1900,560 in 1914 and 1,000 in 1933, while Boots' manufacturing activities were also substantially expanded (Slinn, 1992, 18). Boots became a leading chemists' goods manufacturer, particularly for medicines, and had established an analytical laboratory by the 1890s (by which time Boots was already Britain's largest chemist's chain) (Greenwood and Ingram, 2018: 861).

Boots' managerial systems received a major up-grading following its acquisition by U.S.-based United Drug Co. in 1920 (when an elderly Jesse Boot felt unable to continue running the business). United Drug Co. introduced American-style managerial systems, including profit-sharing remuneration for senior executives, advanced systems of statisticallybased expense and stock control (which also provided performance benchmarks for individual stores) and geographic division of stores into territories, supervised by territorial general managers. ${ }^{\text {xxix }}$ However, US. control was fairly arms-length after the initial modernisation drive, with most senior managers being drawn from Boots staff. In the wake of the Depression Boots was sold back into British control in 1932, under a consortium headed by Jesse Boot's son John (who had remained a senior executive during the period of American control) (Chapman, 1974: 148-50). Boots witnessed further sustained growth in the second half of the twentieth century, taking over its main rival, Timothy Whites and Taylors, in 1968 and, despite several changes 
in ownership, it is still headquartered in Nottingham and retains its identity as a Nottingham firm.

Boots had started to gather archival materials in the 1950s but did not appoint an archivist until the early-1990s (Greenwood and Ingram, 2018: 858). The archive was originally used primarily to answer customer queries and was seen by the company as an information service. The first archivist focused on the development of a purpose-built repository, building up the content, and raising the profile of the collection. More recently the emphasis has been on building awareness of the importance of heritage within the business and thereby creating value for the company. Boots Company Archives were keen to have an external perspective in order to understand the value of their collection to academic users.

The initiative to engage an academic expert arose in $2011 / 12$, when a journalist planned a visit (after visiting the $M \& S$ archive) and the PR team questioned whether they had enough material to make the trip worthwhile. This highlighted the very limited understanding of the wealth of material held by the archive, even among closely-related areas of Boots' activities. ${ }^{\mathrm{xx}}$ The Boots archivist, Sophie Clapp, approached Scott because she felt that there was considerable material in the archive which the business was not finding interesting (too detailed and not obviously relevant to current concerns), for which preservation required a rationale. ${ }^{\mathrm{xxx}}$ Scott was contacted early in 2013 and produced a report in April of that year. ${ }^{\text {xxii }}$ The archives were assessed on the same criteria used for the earlier reports. Once again, the importance of the company was self-evident, given that Boots had dominated British retail pharmacy since the close of the nineteenth century and was also one of Britain's largest retailers, with more than 1,000 stores by the early 1930s. The comprehensiveness of the collection was also clearly demonstrated by the catalogue, with records stretching from the early days of the firm to the present and covering all areas of its operations. The assessment therefore focused on the quality and usefulness of the archival information. 
In common with $\mathrm{M} \& \mathrm{~S}$ and BT, the Boots archive (subsequently rebranded as the Walgreen Boots Alliance Archive - WBAA) was very substantial, containing over 500,000 items (Creenwood and Ingram, 2018, 857). This made it necessary to concentrate on certain areas. In this case the areas chosen were: key corporate reports; managerial accounts and statistical analyses; marketing-related documents; pharmaceutical and other product R\&D; and personnel-related records. The report identified a number of areas of both national and international importance in the collections, including the history of British health care provision; the history of pharmaceutials; and the development of British high-street retailing. Other strengths included marketing-related records (covering virtually the whole of the company's history), which showed the early adoption of U.S. marketing methods and the development of a consistent advertising message before 1900, based around emphasising personal beauty and hygiene.

Records concerning Boots' important role in the development and manufacture of pharmaceuticals, cosmetics, toiletries, and related products included its major contributions in bacteriology; antibiotics; chemotherapy; virology; biochemistry; drug metabolism; and pharmacology. Two areas of particular significance in pharmaceutical development which are extensively-documented in the archives concern work on Penicillin and Penicillin pharmaceuticals and on the development and launch of Ibuprofen.

Furthermore, it identified a range of path-breaking managerial and customer-focused initiatives pioneered by Boots, including employee welfare, appealing to a broad range of customers from an early date ("the classes and the masses") and developing a welcoming environment for women shoppers (Scott and Walker, 2017b: 103-5). The report noted that the WBAA provided considerable scope for exploitation, both internally (given its rich coverage of brand histories, product development, corporate identity and other issues); and externally constituting an important resource for a range of external stakeholders, from secondary 
schools to academic researchers. It particularly emphasised its special importance to the history of pharmaceuticals and to retailing history.

Recommendations included digitising a small sample of the archives, as a way of demonstrating the strengths and breadth of the collection, to increase accessibility and usage. It was also suggested that an online catalogue, or guide to the collections, would be worth consideration. Such initiatives would greatly increase the accessibility of the material to groups such as secondary schools (a potentially important audience, given the inclusion of the history of medicine in the general GCSE history syllabus).

The WBAA staff were very happy with the report. As Sophie Clapp noted: "It was so positive in terms of who would find it useful that it kind of gave us that impetus to reposition ourselves as an academic resource."xxxiii The staff state that the report's key strengths included identifying research groups who might be interested in particular areas of the collection; providing verifification that the archive has value beyond Boots' internal needs; giving an insight into how academics work and therefore what they might be interested in; and providing an overall profile of the records, which has proved valuable both to internal and external users. ${ }^{\text {xxiv }}$

In common with the previous two reports, this report mainly acted to provide external validation of the importance of the archive - which was already obvious to the archive staff, but not to other internal and external stakeholders. However, it did identify some constituencies that the archival staff had not hitherto considered, such as economic geographers. The report also highlighted the wealth of statistical data assembled by Boots, providing key performance measures from the 1920s onwards. Moreover, it gave an insight into how academics work: "It has been a real learning for me and I got a huge amount out of it personally." Xxxv "It has brought real kudos to the collection that (a) people are interested in the history of Boots, (b) the collection is good enough to be able to have multiple Phd's 
working on it in totally different areas and (c) we can pull out some amazing statements that have been independently verified that back-up what we are saying today...It is like the power of the consultant." xxxvi

Sophie Clapp recalls: "I knew the collection was brilliant but actually reading it in black and white was fantastic and gave me real confidence to champion it even more." A copy of the report was sent to the Executive team who responded very favourably to hearing that they had one of the best British corporate archives. Elizabeth Fagan (Senior VicePresident and Managing Director of Boots at the time of the report ) was a big advocate for the archive and gave a good speech at the launch event. ${ }^{\text {xxxvii }}$

Since the production of the report academic engagement with the archive has grown substantially and the archival staff note that the report was fundamental to putting Boots on this path. ${ }^{\text {xxviii }}$ This was assisted by a major five-year grant from the Wellcome Foundation in 2014, to fund cataloguing and preservation of the entire WBAA collection (something which was unusual, as most such bids are for a particular class of archives within a collection). ${ }^{\text {xxix }}$ Scott's report was part of an appendix to the Wellcome bid - which added credibility to the inclusion of the entire archive and highlighted some material that the archive staff would not otherwise have signalled as being important. The report was also instrumental in making the case for the initiative. As Sophie Clapp recalls: "That was the game changer for me."xl

The launch of phase one of the Wellcome-funded on-line catalogue in May 2017 marked a major improvement in the accessibility of the archive's social medical material, together with an on-going archival conservation programme (Greenwood and Ingram, 2018: 858). This digital archive currently (April 2020) comprises around 42,000 entries. ${ }^{\text {xli }}$ The initiative was supported by an academic advisory group which included 14 academics (including Scott) spanning several universities and academic disciplines. The aims of the 
group were to advise on: how the catalogue could be used/ developed for research purposes; how to raise the profile of the collection; to understand key current research topics relevant to the collection; to collaborate with research; and to develop strong relationships with key academics. Boots has also undertaken several other university collaborations since the report, including an international history of the company: "Chemists to the nation, pharmacy to the world", with the University of Nottingham. ${ }^{\text {xlii }}$

Despite the collection's importance for the scientific and social history of medicine, most academic use of its resources has come from business schools (Greenwood and Ingram, 2018: 858). This reflects Boots' status as one of Britain's largest retailers from the late nineteenth century onwards, having more than 1,000 UK stores by the mid-1930s. Moreover, from the late nineteenth century it has been a multi-product store, selling both core pharmacy lines and a range of other products, from photography to (during parts of its history) artistic prints, glassware, and records).

\section{[Figure 3 near here]}

The WBAA has also launched outreach initiatives for communities and schools. This has included a collaboration with Professor Victoria Tischler (University of West London) who works on dementia. This project, initiated by Sophie Clapp, developed from work on Boots Original Beauty Formula. "Memory boxes" were produced containing the smells of perfumes and pictures of the stores. Boots UK did a major campaign in May 2018 for Dementia Action Week, including a film and leaflets in all stores explaining that WBAA had created these memory boxes. The study involves people with mild to moderate dementia, living in a residential home, and their care staff. A range of odours and objects from the archive collection are used to encourage conversation in a group setting. ${ }^{\text {xliii }}$ Evaluation involved a six-week workshop delivered by somebody external to Boots, who recorded the 
results of the work and examined the clinical impact. Tischler's results were published in the peer-reviewed journal Dementia and this initiative also provided funding for her Ph.D support. There were also various local outreach projects involving dementia care (Griffiths et. al, 2019; Tischler and Clapp, 2019) ).

Other initiatives have focused on local out-reach, such as a link with the School of Education at Nottingham University since 2014. They have also developed classroom content in relation to their No7 beauty range exhibition for the History of Medicine GCSE curriculum, with an education box sent out to local schools. The archive has also provided public talks and exhibitions for local Womens Institute and local history groups.

Like M\&S, the Boots Archive has been more widely-used by internal stakeholders following the report and subsequent work to increase the collection's accessibility. Boots' new marketing director, who had not previously worked in a company with an archive, arranged for all her senior team to visit the archive. Sophie Clapp noted that: "There is a very strong emphasis placed on archives with our advertising agency, in terms of really understanding the heritage of some of our brands." xliv There have also been initiatives to boost colleague engagement. For example, in 2017 Boots created a community of people who have worked for them for 50 years (the " 50 year club"), leading to, among other things, a successful book project. ${ }^{x l v}$

Boots has also commercially exploited its heritage - chronicled in its archives. For example, 2016 saw the launch an advertising campaign which took its inspiration from Jesse Boot and his description of Boots as "Chemists of the Nation". xlvi They have also built heritage into product launches including the temporary introduction of retro design packs for its celebrated long-running No7 beauty range (an own-label cosmetics brand introduced by Boots in 1935) and the branding of new product ranges, such as the Florence Annie range. ${ }^{x l v i i}$ 
Similarly, for an exhibition featuring No7, they chose to work with a cultural historian, in order to put the female customer, rather than the business, at the heart of the exhibition. Thus Scott's report was perceived by the company as being more significant than anticipated changing their approach to various activities, to reflect their heritage and academic links. ${ }^{\text {llviii }}$

\section{Discussion and conclusion}

The appraisal reports each represented only one element of the respective companies' wider strategies to develop accessibility and use of their archival resources, initiated prior to the decision to seek expert appraisal. As such, it is impossible to isolate the impact of the appraisals from other key elements of their strategies. However, the three cases do indicate that independent expert appraisal is a useful tool for assessing both the various intangible elements of value in archival collections and their overall importance. While there are alternatives (such as letters of support from previous users of the collection) the appraisal approach has the advantage of reviewing the collection as a whole and judging its value in relation to other major corporate archives. The appraiser's key "expertise" largely consists of long term "immersion" in cooperate archives, providing the tacit knowledge necessary to make judgements of relative academic and cultural value. While this process is, to some extent, subjective, it is no more so than the appraisal of an art expert who judges the (in this case monetary) value of a unique artefact such as a painting on the basis of his/her immersion in the art world.

In the three cases reviewed above, the appraisals generally served to corroborate what the archivists already knew were important strengths of their collections, but had hitherto lacked independent evidence to verify (though some potential users that the archivists had not 
hitherto considered were also identified). Appraisal evidence was probably more important for the companies' top managers, who were much less familiar with the archival collections. The reports also represented valuable independent advice for external bodies; for example in applications for national and international recognition, via UNESCO, Arts Council England, and similar accreditations. Especially in the case of BT and Boots, the appraisals and subsequent accreditations supported much-needed funding to make some of their key resources more accessible, through the creation of on-line catalogues and archive digitisation resources. These are particularly valuable in promoting corporate archives, given that many researchers and other users would not think of contacting company archives (or, in many cases, even be aware of their existence). Business archives are generally much less "visible" than national and local public sector archives, so attracting key external stakeholders requires an active programme of dissemination and publicity, via appropriate print and digital "signposts", the most important of which are online catalogues. BT, M\&S, and Boots plc are among only a hand full of UK companies that have made their archive catalogues available to the public (Turton, 2017: 303).

One unexpected result, emphasised to various extents in all three case-studies, is the deepening and widening of engagement with the archives on the part of internal users. This may, to some extent, reflect a prior surge in interest that precipitated the commissioning of the appraisals. However, the archives' staff note that the reports and - no doubt more importantly - the accreditations and resulting investment and publicity for the collections have led to stronger links between the archives and a range of other corporate functions. These include not only obvious areas for synergies such as branding and heritage, but also corporate training and informing strategic decision-making. The appraisal reports thus appear to have not only raised the external profile of the collections, but also contributed to a process that made them a much more valuable internal resource. 
A final important question is: "what benefits do historians and other academics gain frorm this type of initiative?" First and foremost, any actions that increase the chances of survival, or boost the accessibility, of major corporate archives are clearly of advantage to historians - who (with certain exceptions) regard the analysis of archival documents as their core evidence base and methodology. The loss of such collections would make it much more difficult to examine a broad range of historical topics, from labour relations to environmental history. Co-creation of new resources via academic/archival collaborations can make the historian's work a great deal easier. For example, in the absence of on-line catalogues (or even catalogued collections) historians have to weigh up the likelihood of finding useful information in a repository against the time and monetary costs of travelling to visit it, based on minimal information. With an on-line catalogue, most of the searching can be done even before the visit. The initiative also shows the value researchers can gain from undertaking a general review of what resources archival repositories can provide for their research questions (or find answers to questions they had not previously considered). This was certainly the case for Scott, whose reviews of the three archives led directly to the production of three journal articles, together with two book chapters; plus two Ph.D. theses undertaken by his students (Scott, 2011; 2017; Scott and Walker, 2017a; 2017b; 2018; Buckley, 2017; Hull, 2017).

For most historians the value of a comprehensive, accessible, archive is self-evident. However, while quantitative historians may devote substantial resources on new datasets, historians who use archives often fail to consider their responsibility to safeguard and support the respositories that constitute their principal source material. Accessible corporate archives will only survive, let alone thrive, with the support of current and potential users, including both elements of co-creation, and of independent expert advice, to evaluate the value and scope of the riches they hold. 


\section{References}

Adkins, E.W. 1977. "The Development of Business Archives in the United States: an

Overview and a Personal Perspective." American Archivist, 60, 1: 8-33.

Anderson, H.P. 1982. "Business Archives: a Corporate Asset.” American Archivist, 45, 3: 264-266.

Ataman, B.K.. 2009. "How to Make the Most of Archives for Public Relations.” American Archivist, 72, 1: 197-213.

Bakken, D.S. 1982. “Corporate Archives Today.” American Archivist, 45, 3: 279-286.

Bookbinder, P. 1993. Simon Marks, Retail Revolutionary. London: Weidenfeld \& Nicolson.

Briggs, A.1984 Marks \& Spencer 1884-1984. A Centenary History of Marks \& Spencer.London: Octopus, 1984.

Buckley, T.R. 2017. "The Productivity of Large-Scale Retail Organisations in Britain 19501980,' unpublished Ph.D. thesis, University of Reading.

Carter, K. 2013. “The M\&S Company Archive: from Penny Bazaar to Research Resource.” Business Archives, 107: 1-19.

Chapman, S. 1974. Jesse Boot of Boots the Chemists. London: Hodder \& Stoughton.

Chapman, S. 2004. "Boot, Jesse, first Baron Trent (1850-1931)." Oxford Dictionary of National Biography, Oxford University Press.

Deserno, I. 2009. 'The Value of International Business Archives; The Importance of the Archives of Multinational Companies in Shaping Cultural Identity,' Archival Science, 9: 215225. 
Donze, P. and A. Smith. 2018. "Varieties of Capitalism and the Corporate Use of History: the Japanese Experience," Management and Organizational History, 13, 3: 236-257;

Foreman-Peck, J., D. Raff, and P. Scott. 2019. "Introduction: Leslie Hannah and Business History in his Time," Business History, 61, 7: 1091-1107.

Foster, W., D.M Coraiola, R. Suddaby, J. Kroezen, and D. Chandler. 2017. “The Strategic Use of Historical Narratives: a Theoretical Framework.” Business History, 59, 8: 1176-1200.

Gray, V. 2002. "Developing the Corporate Memory: The Potential for Business Archives," Business Information Review, 1: 32-37.

Green, A.R. and E. Lee. 2020. "From Transaction to Collaboration: Redefining the Academic-Archivist Relationship in Business Collections,' Journal of the Archives and Records Association, 41, 1): 32-51.

Greenwood, J.E. 1977. A Cap for Boots: An Autobiography. London: Hutchinson. Greenwood A. and H. Ingram. 2018. “'The People's Chemists': the Walgreens Boots Archive Alliance,' Social History of Medicine, 31, 4: 857-869.

Griffiths, S., Dening, T,. Beer, C., Tischler, V.. 2019. "Mementos from Boots Multisensory Boxes - Qualitative Evaluation of an Intervention for People with Dementia." Innovative practice. $18,2: 793-801)$.

Hatch, M.J. and M. Schultz. 2017. "Toward a Theory of Using History Authentically: Historicising in the Carlsberg Group,"Administrative Science Quarterly, 62, 4: 657-697. Hay, D. 2004. “BT's Connected Earth: A New Model for Safeguarding A Corporate Heritage Collection.” Business Archives, 87: 45-60.

Hull, A.C. 2017. "Performance Management and Measurement : the Experience of British Multiple Retailers 1920 to 1970,' unpublished Ph.D. thesis, University of Reading, 2017. 
Lasewicz, P.C. 2014. "The View from the Ivory Tower: the Academic Perspective on the Strategic Value of Corporate History and Heritage.' 103-122 in in Alexander L. Bieri et. al., Crisis, Credibility and Corporate History. Proceedings of the Symposium of the International Council on Archives, section on Business and Labour Archives, 14-16 April 2013, Basel Liverpool: Liverpool University Press. Lasewicz, P.C. 2015. "Forget the Past. Or History Matters? Selected Academic Perspectives on the Strategic Value of Organizational Pasts,' American Archivist, 78, 1: 59-83. Logan, K. 2017. “An Introduction to Business Archives," 3-31 in Alison Turton (ed.), The International Business Archives Handbook. London: Routledge.

Rees, G. 1969. St Michael. A History of Marks \& Spencer.London: Pan.

Scott, P. 2011. "Still a niche communications medium: the diffusion and uses of the telephone system in interwar Britain', Business History, 53: 801-20.

Scott, P. 2017. The Market Makers. Creating Mass Markets for Consumer Durables in Interwar Britain. Oxford: Oxford U. P.

Scott, P. and J.T. Walker. 2017a. "Barriers to 'Industrialisation' for Interwar British retailing? The Case of Marks \& Spencer Ltd.” Business History, 59: 179-201.

Scott, P. and J.T. Walker. 2017b. "Large-Scale Retailing, Mass-Market Strategies and the Blurring of Class Distinctions in Inter-War Britain." 99-126 in P. Di Martino, A. Popp, and P. Scott (eds), People, Places and Business Cultures. Essays in Honour of Francesca Carnevali.Woodbridge: Boydell.

Scott, P. and J.T.Walker. 2018. "Retailing under resale price maintenance: Economies of scale and scope, and firm strategic response, in the inter-war British retail pharmacy sector." Business History, 60: 807-832.

Slinn, J. 1992. “The Boots Company plc." In St James Press, International Directory of Company Histories. London: St. James Press: 17-20. 
Smith, A. and D. Simeone. 2017. "Learning to use the Past: the Development of a Rhetorical History Strategy by the London Headquarters of the Hudson's Bay Company," Management and Organisational History, 12, 4 (2017); 344-356

Tischler, V. amd Clapp, S. 2019. "Multi-sensory Potential of Archives in Dementia Care, Archives and Records (published online 2019, DOI: 10.1080/23257962.2019.1675147). Turton, A. 2017. “Access." 293-315 in Alison Turton (ed.), The International Business Archives Handbook. London: Routledge, 2017.

Wishermann, C. 2014. "Business History or Corporate Communication,” 13-22 in A. L. Bieri et. al., Crisis, Credibility and Corporate History. Proceedings of the Symposium of the International Council on Archives, section on Business and Labour Archives, 14-16 April 2013, Basel. Liverpool: Liverpool University Press.

Wright, S.L. 1996. "Love Me or Leave Me: Getting Businesses Interested in Archives." Archival Issues, 21, 2: 159-168. 
Figure 1: Part of the Marks in Time exhibition at the M\&S Company Archive, Leeds.

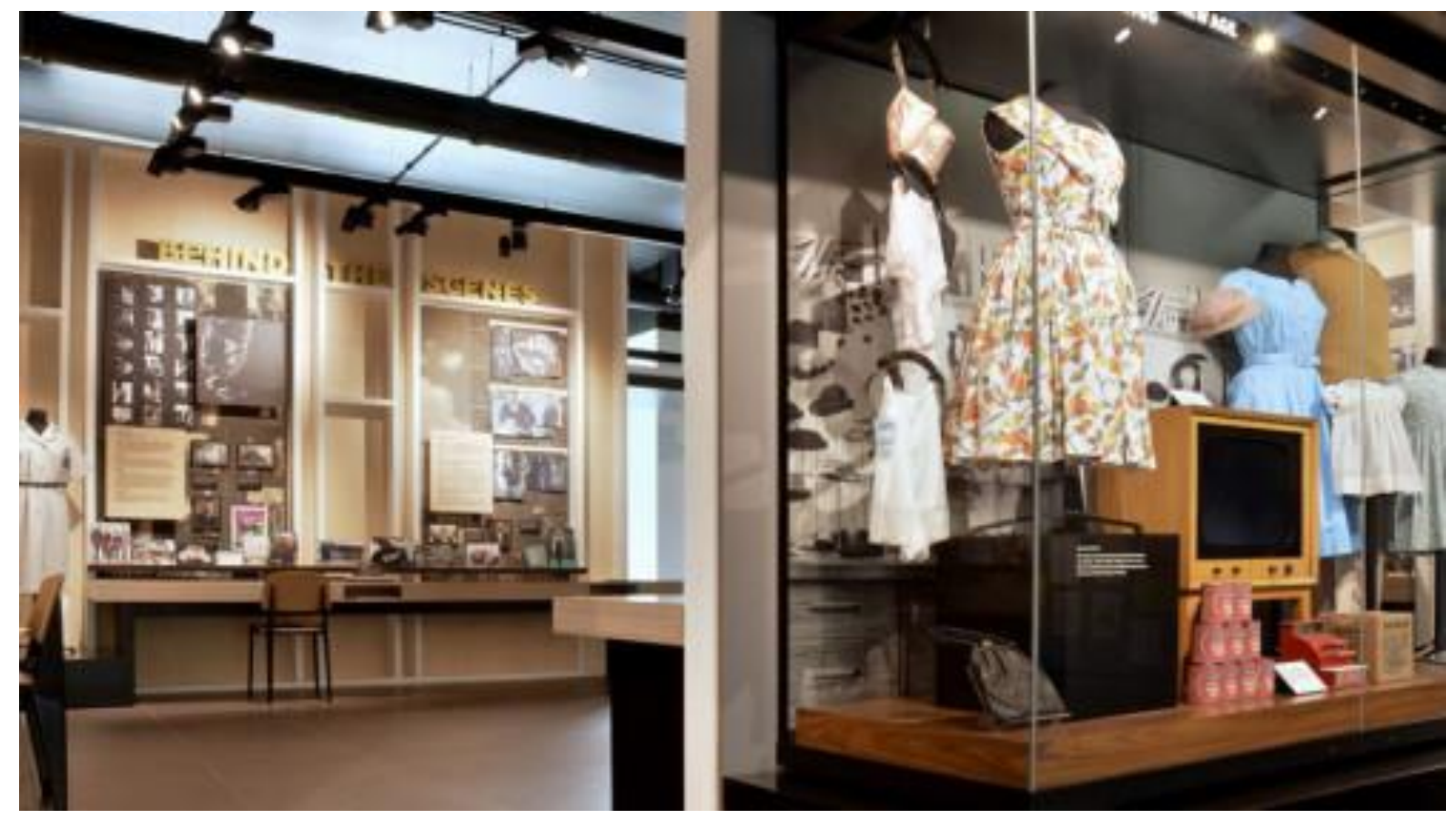

Source: https://marksintime.marksandspencer.com/home (accessed $28^{\text {th }}$ April 2020). 
Figure 2 Colossus pictured in 1943

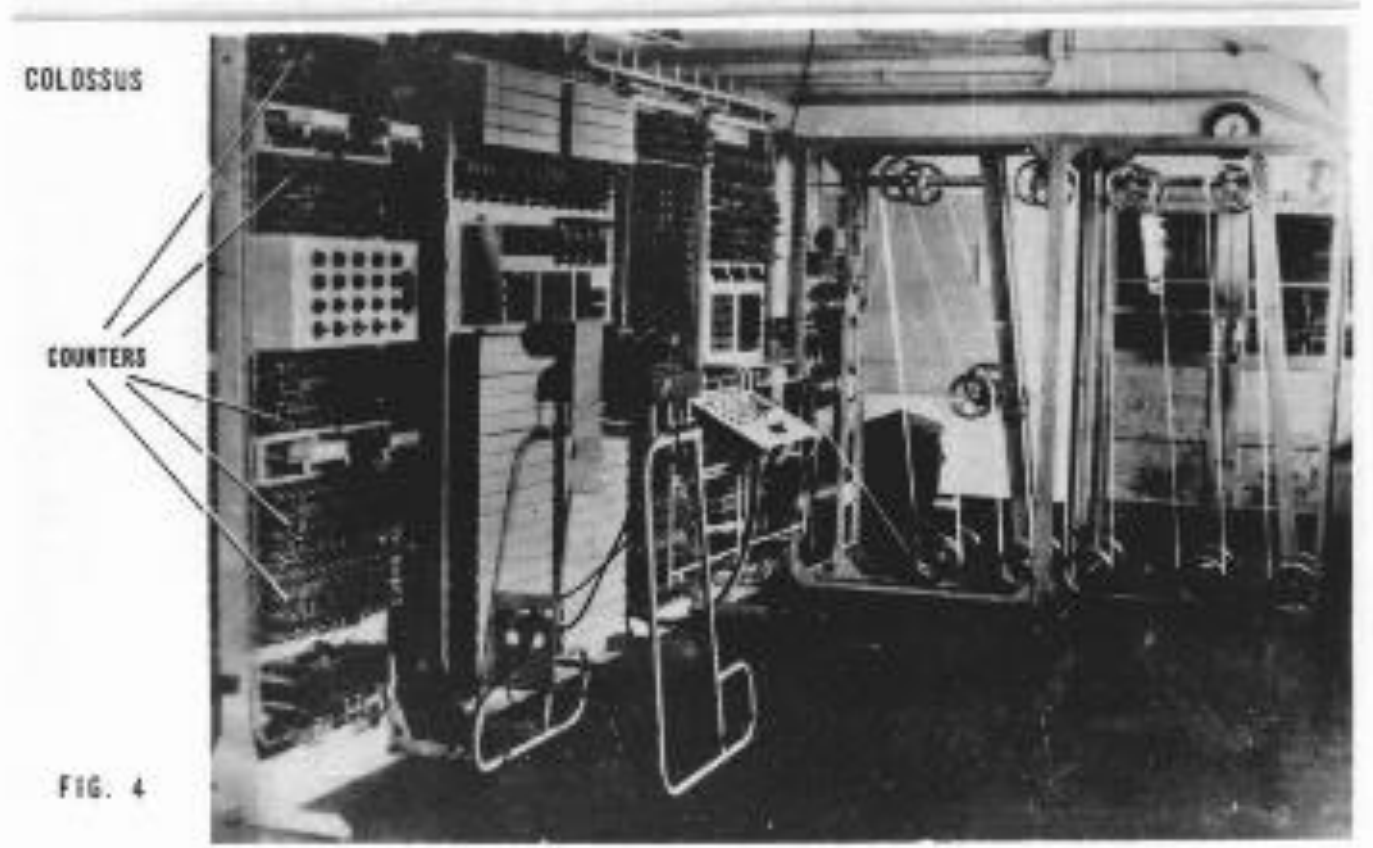

Source: BT Digital Archives, http://www.digitalarchives.bt.com/CalmView/Overview.aspx, TCB 417/E79932, 1943. 
Figure 3: Boots" "In the service of health and beauty," advertisement, c. 1933.

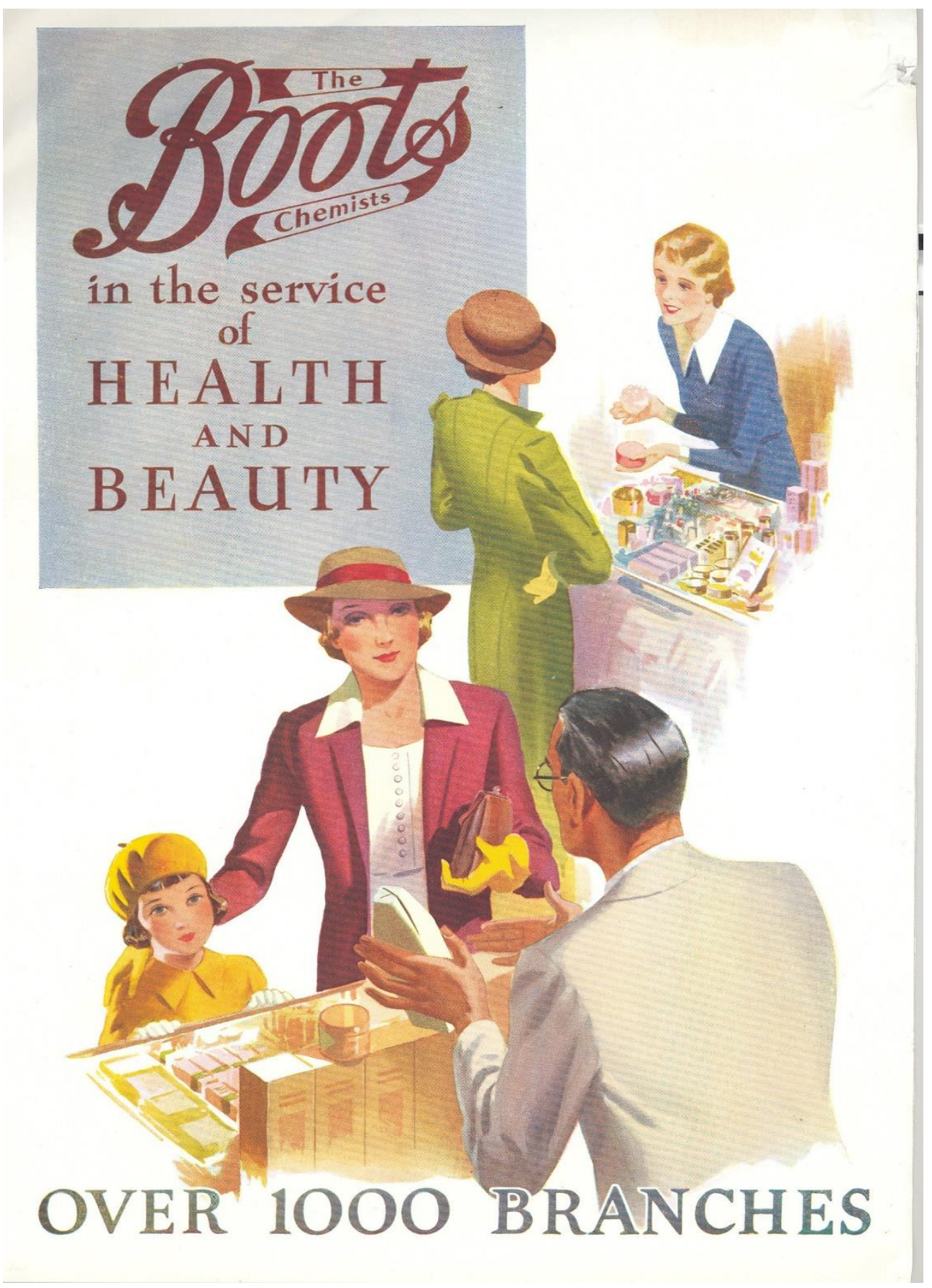

Source: Walgreens Boots Alliance Heritage, WBA/BT/11/45/2/200,

http://archives.walgreensbootsalliance.com/Record.aspx?src=CalmView.Catalog\&id=WBA\%2fBT\%2f $11 \% 2 f 45 \% 2 \mathrm{f} 2 \% 2 \mathrm{f} 200 \&$ pos $=1$ 


\footnotetext{
' 'Using History, Valuing Archives,' Henley Business School workshop, 28 February - 1 March 2019, https://www.henley.ac.uk/events/using-history-valuing-archives-1
}

ii The National Archives, Business archives strategy 2009), https://www.nationalarchives.gov.uk/archivessector/projects-and-programmes/business-archives-strategy/ (accessed 24 April 2020); The National Archives and History UK, Guide to Collaboration for Archives and Higher Education (London: The National Archives, 2018).

iii Peter Scott, "The Marks \& Spencer Company Archive: An academic appraisal," report for Marks \& Spencer plc, $20^{\text {th }}$ March 2008.

iv Interview with Katharine Carter, M\&S Archvist, 8 May 2019.

v Interview with Katharine Carter, M\&S Archvist, 8 May 2019. See also 'Marks in Time - Community Groups and Reminiscence', available online: https://marksintime.marksandspencer.com/community

${ }^{v i}$ M\& S press release:

https://www.leeds.ac.uk/news/article/3015/m_and_s_company_archive_to_open_at_university

vii Marks in Time: https://marksintime.marksandspencer.com/ms-history/timeline/art1279)

viii M\&S chairman's statement in Strategy Report accompanying the Annual Report 2015, p. 2.

ix Interview with Katharine Carter, M\&S Archvist, 8 May 2019

${ }^{x}$ Ibid.

${ }^{x i}$ Ibid.

xii Ibid.

xiii https://www.leeds.ac.uk/forstaff/news/article/4344/thank_you_for_shwopping

xiv ‘Our History', BT. Available online: https://www.btplc.com/Thegroup/BTsHistory/index.htm

${ }^{x v}$ Ofcom (2019) Telecommunication Market Update Q1. Available online: https://www.ofcom.org.uk/researchand-data/telecoms-research/data-updates/telecommunications-market-data-update-q1-2019

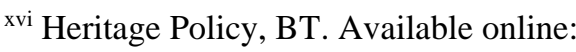

https://www.btplc.com/Thegroup/BTsHistory/BTgrouparchives/OurHeritagePolicy/HeritagePolicy_09.pdf

xvii Interview with David Hay and Anne Archer, BT archives, 2 May 2019.

xviii Ibid.

xix Ibid.

${ }^{x x}$ Peter Scott, "The BT Archive: An academic appraisal, report for BT Archives,” 2 October 2009. 
xxi Ibid.

xxii Arts Council England Designation Scheme: http://www.artscouncil.org.uk/what-we- do/supportingmuseums/designation-scheme/

xxiii https://www.btplc.com/Innovation/History/Timeline/index.htm

${ }^{x x i v}$ https://bletchleypark.org.uk/news/bletchley-park-to-open-new-d-day-visitor-experience-in-2019-thanks-to-

bt-partnership.

${ }^{x x v}$ David Hay, "New Connections: The BT Digital Archives Project", paper presented at the Archives and Cultural Industries Conference, Girona, 11th-15th October 2014.

xxvi

xxvii https://www.btplc.com/Thegroup/BTsHistory/BTgrouparchives/Digitalarchivesandcatalog

ue/index.htm

xxviii Interview with David Hay and Anne Archer, BT archives, 2 May 2019; Hay, D. (2014), 'New Connections: The BT Digital Archives Project', paper presented at the Archives and Cultural Industries Conference, Girona, 11th-15th October.

${ }^{x x i x}$ Boots Archives, A89/33, document setting out the duties of territorial general managers, n.d., c. 1934-38;

“Accounts and Why?” The Bee, March 1922, 13-14; Chapman, Jesse Boot, 151; Greenwood, Cap for Boots, 2124.

${ }^{x x x}$ Interview with Sophie Clapp, Boots archvist, 7 May 2019.

xxxi Ibid.

xxxii Peter Scott, The Boots Company Archives: An academic appraisal, a report for Boots plc, , 15th April 2013.

xxxiii Interview with Sophie Clapp, Boots archvist, 7 May 2019.

xxxiv Ibid.

xxxv Ibid.

xxxvi Interview with Sophie Clapp, Boots archvist, 7 May 2019.

xxxvii Ibid; Boots' corporate website, 'A New Shop Window Opens into Nottingham's Past,' accessed $8^{\text {th }}$ January 2020, https://www.boots-uk.com/our-stories/a-new-shop-window-opens-into-nottingham-s-past/

xxxviii Interview with Sophie Clapp, Boots archvist, 7 May 2019.

xxxix Wellcome web-site, https://wellcome.ac.uk/funding/people-and-projects/grants-awarded/cataloguing-

preservation-boots-archive, accessed 6 ${ }^{\text {th }}$ December 2019.

${ }^{\mathrm{xl}}$ Interview with Sophie Clapp, Boots archvist, 7 May 2019.

xli Walgreens Boots Alliance Heritage website, http://archives.walgreensbootsalliance.com/, accessed $21^{\text {st }}$ April 2020.

xlii https://www.nottingham.ac.uk/vision/pharmacy-to-the-world Sept. 2019.

xliii Ibid.

xliv Interview with Sophie Clapp, Boots archvist, 7 May 2019.

xlv https://www.boots.jobs/boots-50-year-club/ and https://www.boots.jobs/boots-50-year-club-2018/

xlvi James Swift, 'Boots channels 'chemist of the nation' heritage for new brand campaign,' Campaign I (13

May 2016), https://www.campaignlive.co.uk/article/boots-channels-chemist-nation-heritage-new-brand-

campaign/1394844 
xlvii See https://www.no7beauty.com/uk/about-us, accessed 28 ${ }^{\text {th }}$ April 2020.

xlviii Interview with Sophie Clapp, Boots archvist, 7 May 2019. 